\title{
Evaluation of Serum Tenascin C Level in Patients with Erectile Dysfunction N.W.Michael ${ }^{1}$, E.M.Akl ${ }^{1}$, A.A.Al-Fallah ${ }^{2}$ and M.K.Sultan ${ }^{1}$ \\ ${ }^{1}$ Dermatology, Venereology and Andrology Dept., Faculty of Medicine, Benha Univ.,Benha, Egypt \\ ${ }^{2}$ Clinical and Chemical Pathology Dept., Faculty of Medicine, Benha Univ., Benha, Egypt \\ E-Mail: Sultan66@gmail.com
}

\begin{abstract}
To evaluate serum level of Tenascin $\mathrm{C}$ in vasculogenic erectile brokenness patient and its relationship. Erectile brokenness (ED) is industrious failure to accomplish or keep up inflexible penile erection adequate for agreeable sexual execution. ED is viewed as of vascular beginning in by far most of the patients. Tenascin C protein (TN C) has an immediate job in vascular occlusive redesigning with deferred neointimal arrangement. Tenascin $\mathrm{C}$ can be considered as a potential biomarker in obsessive conditions portrayed by tissue injury and fibrosis. This examination included 80 Participants partitioned into two gatherings; bunch I included 50 patients determined by penile Doppler to have psoriasis and gathering II included 30 ( age and sex coordinated) evidently sound volunteers as a control. serum level of TN-C was estimated utilizing ELISA method in ED patients and contrasted with control bunch The consequences of our examination uncovered that patients had high measurably huge higher TN-C $(\mathrm{p}<0.011)$ than control group.
\end{abstract}

Key words: Erectile dysfunction, Tenascin C (TN-C).

\section{Introduction}

Erectile brokenness (ED) is the industrious powerlessness to accomplish and additionally keep an erection adequate to allow palatable sexual execution. Erectile brokenness is a clinical issue that seriously influences the personal satisfaction of the two patients and their sexual accomplices. ED is viewed as of vascular source in by far most of the patients, because of atherosclerotic injuries of the penile veins. ED is all the more every now and again found in patients with cardiovascular illnesses and its connected danger factors [1].

Loss of consistence of the penile sinusoids related with expanded statement of collagen and diminished flexible strands might be found in diabetes, hypercholesterolemia, vascular sickness, penile injury, or mature age. There is a critical contrast in the mean level of versatile filaments in the penis: $9 \%$ in ordinary men, $5.1 \%$ in patients with venous spillage, and $4.3 \%$ in patients with blood vessel sickness [2].

Changes in smooth muscle substance and ultrastructure can be relied upon to influence erectile reaction. There is critical distinction between the mean rates of huge smooth muscle in ordinary powerful men and those with vasculogenic erectile brokenness. There is additionally debilitation of nerve-evoked unwinding and $\alpha$-adrenergic animated constriction of enormous muscle just as diminished muscle content in men with venous or blended venous/blood vessel erectile dysfunction [3].

Tenascin $\mathrm{C}(\mathrm{TN}-\mathrm{C})$ is a glycoprotein that in people is encoded by the TNC quality, It is communicated in the extracellular network of different tissues during improvement, illness or injury, and in confined neurogenic regions of the focal sensory system. Tenascin-C is the establishing individual from the tenascin protein family. In the incipient organism it is made by moving cells like the neural peak; it is additionally plentiful in creating ligaments, bone and ligament [4].

A significant part of the useful investigations are construed from different TN-C knockout mice models. TN-C obviously assumes a part in cell motioning as confirmed by its capacity to be instigated during occasions like injury, aggravation, or malignant growth improvement. Likewise, TN-C is significant in managing cell multiplication and relocation, particularly during formative separation and wound recuperating [5].

Tenascin C keeps on being explored as a potential biomarker for various illnesses like myocarditis and various types of disease. The various associations with cell working and flagging make TN-C a mainstream protein to concentrate in growing new treatments and discovery strategies [6].

Tenascin $\mathrm{C}$ (TN-C) can be considered as a potential biomarker in neurotic conditions described by tissue injury, fix, irritation and fibrosis [5].

\section{Materials and methods \\ 2.1The study population}

This is a case-control study .The current investigation had been led between March 2019 and April 2020. after the endorsement by Research Committee at Faculty of Medicine, Benha University. The examination included 80 subjects that were haphazardly chosen from those going to the Dermatology Outpatient's Clinic at Benha University Hospital, Faculty of Medicine, Benha University, Qalyobia, Egypt. Preceding commencement of the investigation, each subject was educated about the point of the examination and an educated assent was acquired from every person before test assortment. They were isolated into two gatherings; bunch I included 50 patients determined by duplex US to have erectile brokenness (ED). Guys whom were hitched, explicitly dynamic, matured between 4169 years and gathering II included 30 ( age coordinated) obviously sound volunteers as a controls.

\subsection{ELISA Assays of TN-C}

Quantitative conclusions of serum TN-C were accomplished utilizing a twofold counter acting agent sand with Enzyme Linked Immune Sorbent Assay method (ELISA) was utilized to identify serum level of 
TN-C utilizing a business Human survivin ELISA Kit for research use only .

\subsection{Statistical Analysis}

The collected data were recorded on a report form. These data were tabulated and analysed using the computer program SPSS (Statistical package for social science) version 20 to obtain: Descriptive statistics were calculated for the data in the form of: Mean and standard deviation $( \pm S D)$. for quantitative data and Frequency and distribution for qualitative data. Analytical statistics : In the statistical comparison between the different groups, the significance of difference was tested using one of the following tests, Student's t-test:- Used to compare mean of two groups of quantitative data, ANOVA test (F value):-Used to compare mean of more than two groups of quantitative data and Inter-group comparison of categorical data was performed by using chi square test $\left(\mathrm{X}^{2}\right.$-value). Correlation coefficient: - to find relationships between variables.

A $p$ value $<0.05$ was considered statistically significant $(*)$ while $>0.05$ statistically insignificant.

\section{Results}

This study included 80 subjects whom were divided into two groups. The first group included 50 patients with vasculogenic erectile dysfunction, whom ages ranged between 41 and 69 years. The second group included 30 apparently healthy age matched men who served as controls. All patients had vasculogenic erectile dysfunction ( 50 patients), proved by penile duplex, 33 with venogenic erectile dysfunction, 10 with arteriogenic erectile dysfunction and 7 with mixed arteriogenic/venogenic erectile dysfunction. Among the 50 cases, 34 patients were smokers and 16 were nonsmokers.

Table (1) Comparison between cases according to smoking and type of vasculogenic erectile dysfunction.

\begin{tabular}{lc}
\hline Case group (50) & $\mathbf{n}(\%)$ \\
\hline Smoking & \\
Yes & $34(68.0)$ \\
No & $16(32.0)$ \\
Doppler & \\
Venogenic & $33(66.0)$ \\
Arteriogenic & $10(20.0)$ \\
Mixed & $7(14.0)$ \\
\hline
\end{tabular}

International index of erectile dysfunction (IIEF) questionnaire was filled by the patients with mean score $12.98 \pm$ SD 4.33 .

Peak systolic velocity (PSV) and end diastolic velocity ( EDV), both were measured by penile duplex US scanning, the mean PSV was $34.32 \mathrm{~mL} / \mathrm{s} \pm$ SD 15.91 $\mathrm{mL} / \mathrm{s}$ and mean EDV was $7.02 \mathrm{~mL} / \mathrm{s} \pm \mathrm{SD} 3.63 \mathrm{~mL} / \mathrm{s}$ Table (2).
Fasting blood glucose (FBG) was measured for all patients group with mean FBG $162.38 \mathrm{mg} / \mathrm{dl} \pm \mathrm{SD}$ $69.51 \mathrm{mg} / \mathrm{dl}$.

Systolic blood pressure (SBP) was measured for all patients group with mean SBP $143.6 \mathrm{~mm} / \mathrm{Hg} \quad \pm \mathrm{SD}$ $14.95 \mathrm{~mm} / \mathrm{Hg}$, while mean diastolic blood pressure (DBP) was $84.6 \mathrm{~mm} / \mathrm{Hg} \pm \mathrm{SD} 6.84 \mathrm{~mm} / \mathrm{Hg}$.

Table (2) Distribution of case group according to clinical findings.

\begin{tabular}{lcccc}
\hline & \multicolumn{4}{c}{ Case group $\mathbf{5 0})$} \\
\cline { 2 - 5 } & Mean & $\mathbf{\pm S D}$ & Min & Max \\
\hline FBG mg/dl & 162.83 & 69.51 & 74.0 & 304.0 \\
SBP $\mathbf{~ m m} / \mathbf{H g}$ & 143.6 & 14.95 & 110.0 & 175.0 \\
DBP mm/Hg & 84.6 & 6.84 & 75.0 & 118.0 \\
IIEF & 12.98 & 4.33 & 5.0 & 20.0 \\
PSV m/s & 34.32 & 15.91 & 13.0 & 57.0 \\
EDV m/s & 7.02 & 3.63 & 0.4 & 19.0 \\
\hline
\end{tabular}

This study showed that there was a significant difference between patients group and control group regarding serum level of Tenascin $C$ with $p$ value $<0.011 * *$ Table(3).
Serum level of Tenascin C (S TN-C) was measured by ELISA technique for both patients and control groups. Mean of serum TN-C for patients was $16.89 \mathrm{ng} / \mathrm{dl} \pm \mathrm{SD}$ $12.61 \mathrm{ng} / \mathrm{dl}$. Mean of serum TN-C for controls was 9.13 $\mathrm{ng} / \mathrm{dl} \pm \mathrm{SD} 5.29 \mathrm{ng} / \mathrm{dl}$. 
Table (3) Comparison between case and control groups according to TN C.

\begin{tabular}{|c|c|c|c|c|c|c|}
\hline & \multicolumn{2}{|c|}{ Case group (50) } & \multicolumn{2}{|c|}{ Control group (30) } & \multirow[t]{2}{*}{ Statistical test } & \multirow[t]{2}{*}{ p value } \\
\hline & mean & \pm SD & mean & \pm SD & & \\
\hline S TN-C ng/dl & 16.89 & 12.61 & 9.13 & 5.29 & St $t=2.54$ & $<0.011 * *$ \\
\hline
\end{tabular}

This study showed that there was significant positive correlation between serum level of TN-C and smoking with $p$ value $<0.05$ Table(4).

Table (4) S TN-C differences among smokers.

\begin{tabular}{|c|c|c|c|c|}
\hline \multirow[t]{2}{*}{ Case group (50) } & \multicolumn{4}{|c|}{ S TN-C } \\
\hline & Mean & \pm SD & Statistical test & p value \\
\hline \multicolumn{5}{|l|}{ Smoking } \\
\hline Yes 34 & 16.98 & 12.71 & St $t=0.39$ & $<0.05^{*}$ \\
\hline No 16 & 10.09 & 9.80 & & \\
\hline
\end{tabular}

This study showed that there was a significant correlation between serum level of $\mathrm{TN}-\mathrm{C}$ andDisease duration with $\mathrm{p}$ value $<0.001^{* *}$.
This study showed that there was significant positive correlation between serum level of TN-C and cardiac diseases with $\mathrm{p}$ value $<0.042$.

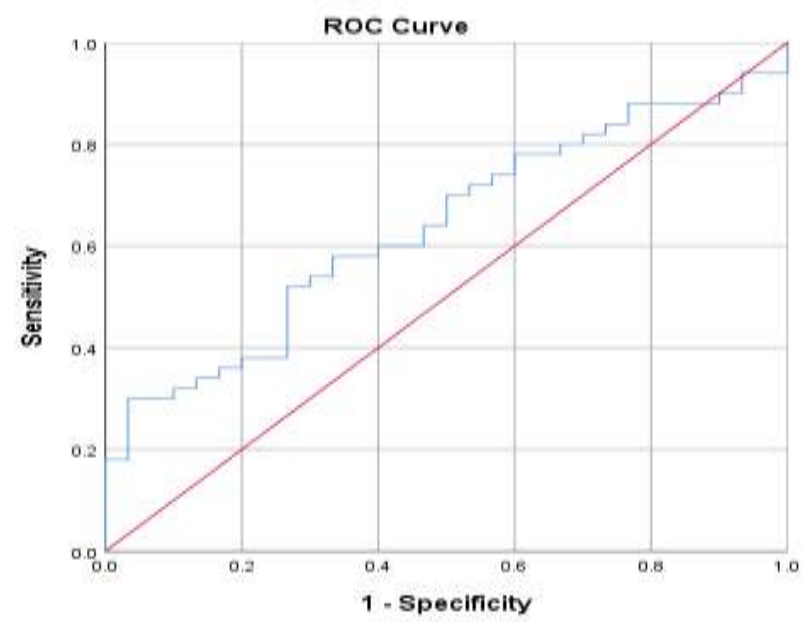

Fig (1) ROC curve for the performance of TN-C in detection of erectile dysfunction.

\section{Discussion}

Erectile brokenness is a clinical issue that seriously influences the personal satisfaction of the two patients and their sexual accomplices. Erectile brokenness is viewed as of vascular source in by far most of the patients, because of atherosclerotic sores of the penile supply routes. It is in this manner not amazing that erectile brokenness is all the more every now and again found in patients with cardiovascular sickness and danger factors than in people without such conditions [7].

Tenascin $\mathrm{C}$ is an assorted protein that can create various capacities inside a similar cell type. This heap of capacities is cultivated through elective grafting of mRNA just as the worldly initiation of sign transduction pathways and additionally target qualities at various phases of development or differentiation [8].

The point of this examination was to assess serum level of Tenascin $\mathrm{C}$ (TN-C) in patients with vasculogenic erectile brokenness. This investigation included 50 patients demonstrated by Duplex US as vasculogenic ED and 30 clearly sound men matured coordinated, consequences of this examination showed that there is huge rise of serum levels of Tenascin $\mathrm{C}$ in patients with vasculogenic ED with $\mathrm{p}$ esteem $<0.011^{*}$.

The age of the patients remembered for this examination ran somewhere in the range of 41 and 69 years with mean time of 52.3 year and standerd deviation \pm 10.98 , recommending expanded frequency of ED with expanded age, this went with [9].

Among the fifty patients remembered for this investigation, 34 were smokers. This went with expanded frequency of ED among smokers, predictable with[10]. In this examination, among the 34 smokers patients included, the mean of Tenascin C was 16.98 with critical rise than control gathering, recommending that Tenascin $\mathrm{C}$ expanded in site of irritation, this went with past investigations[11]. 
Fasting blood glucose estimated for patients in this examination showed that the mean FBG was 168.38 $\mathrm{mg} / \mathrm{dl}$ with standerd deviation $\pm 69.51 \mathrm{mg} / \mathrm{dl}$. This backings diabetes milletus as a danger factor for ED in concurrence with[12].Other investigations relating Tenascin $\mathrm{C}$ with hazard factors related with $\mathrm{ED}$, as diabetes milletus, TN-C has been showed height in diabetes initiated retinopathy,[13]whom checked on impacts of Tenascin-C on ordinary and diabetic retinal endothelial cells. Albeit in this investigation Tenascin C is raised in diabetic patients with ED without positive connection, might be because of low number of patient or variation sickness length.

Among the fifty patients remembered for this examination, 34 patients had foundational hypertension, with mean SBP $143.6 \mathrm{~mm} / \mathrm{Hg} \pm \mathrm{SD} 14.95 \mathrm{~mm} / \mathrm{Hg}$ and mean diastolic circulatory strain (DBP) was $84.6 \mathrm{~mm} / \mathrm{Hg}$ $\pm \mathrm{SD} \quad 6.84 \mathrm{~mm} / \mathrm{Hg}$. These outcomes uphold the relationship among hypertension and erectile brokenness, this went with[14].

Among the fifty patients remembered for this examination, 28 patients had a background marked by cardiovascular illnesses. Supporting that there is increment in frequency of ED among patients with heart illnesses, steady with.(15) In this investigation, among 28 cardiovascular patients with ED the mean of Tenascin $\mathrm{C}$ was 18.96 and fundamentally raised than non heart patients with $\mathrm{p}$ esteem 0.042 , proposing that there is increment in site of weakened flexibility, that went with[16].

Among fifty patients remembered for this investigation, the outcome showed profoundly certain relationship between's Tenascin $\mathrm{C}$ and illness term with $\mathrm{p}$ esteem $=<0.001 *$, These outcomes upheld by different examinations,[16] that audited the relationship between serum TN-C levels and infection length in patients of cardiovascular breakdown.

In this investigation the lab consequences of Tenascin $\mathrm{C}$ assessment of patients gathering (50 patients) was higher with Mean 16.89 in Comparison with Controls gathering (30 men ) with Mean 9.13, which show a critical contrast with $\mathrm{p}$ esteem $<0.011^{*}$.

This investigation showed that serum level Tenascin $\mathrm{C}$ was fundamentally higher in vasculogenic ED male patients bunch than controls male group.

\section{Summary}

This Ponder meant will assess serum level from claiming Tenascin c over patients for vasculogenic erectile brokenness.

Eighty persons(50)patients for vasculogenic ED, demonstrated by penile doppler, ages went between 41 and 69 with imply agdistis (years) 52. $38 \pm$ SD 10.98 and 30 males, agdistis matched Obviously solid volunteers were incorporated in this examine.

The study demonstrated that there might have been An critical distinction the middle of patients and controls in regards serum level of Tenascin c with imply serum level for Tenascin c's $16.89 \mathrm{ng} / \mathrm{dl} \pm \mathrm{SD} 12.61 \mathrm{ng} / \mathrm{dl}$ to cases, What's more 9. $13 \mathrm{ng} / \mathrm{dl} \pm \mathrm{SD} 5.29 \mathrm{ng} / \mathrm{dl}$ to controls with $\mathrm{p}$ esteem $<0.011^{*}$.

The study Additionally indicated that there might have been a critical sure correspondence the middle of serum level about Tenascin c's What's more infection span for. ED.

\section{Conclusions}

Starting with the bring about shortages for our examine ,it is finished up that TN-C level might have been raised done vasculogenic ed, Tenascin c protein (TN-C) might be advantageous in deciding those association between the state for versatility of the blood vessels inside the corpora of the penis What's more advancement about vasculogenic erectile brokenness.

\section{Recommendations}

Bigger example are necessary will assess serum level of TN-C On patients for ed. Over further studies, strict catch up to assess the vitality about Tenascin c's in the medication regimens for erectile. dysfunction.

\section{References}

[1] K.Hatzimouratidis, I.Eardley, F.Giuliano, et al. EAU guidelines on penile curvature. EurUrol 2012 Sep. Vol.62(3), PP.543-52, 2012.

[2] C.Gratzke, J.Angulo, Chitaley Kim, et al. Anatomy, Physiology, and Pathophysiology of Erectile Dysfunction. J Sex Med . Vol. (7), PP. 445-475, 2010.

[3] Y.Tan, W.N.Landford, et al. Complete Human Penile Scaffold for Composite Tissue Engineering: Organ Decellularization and Characterization. Sci Rep. Vol. 9, PP.16368, 2019.

[4] D.E.Nies, T.J.Hemesath, J.H.Kim, J.R.Gulcher, K.Stefansson. "The complete cDNA sequence of human hexabrachion (Tenascin). A multidomain protein containing unique epidermal growth factor repeats". J Biol Chem. 266. Vol. (5), PP. 2818-23, 1991.

[5] H.P.Erickson. "Tenascin-C, tenascin-R and tenascin$\mathrm{X}$ : a family of talented proteins in search of functions". Curr. Opin. Cell Biol. Vol. 5(5), PP.869-76, 1993.

[6] Kyoko Imanaka-Yoshida, Michiaki Hiroe, Yasuhiro Yasutomi, Tetsuya

Toyozaki, Takuro Tsuchiya, Naomi Noda, Toshiki Maki, Toshio Nishikawa, Teruyo Sakakura, Toshimichi Yoshida. Tenascin-C is a useful marker for disease activity in myocarditis,J Pathol. Vol.197(3), PP.388-94, 2002.

[7] F.Baumann, D.Hehli, V.Makaloski, et al. Erectile dysfunction - overview from a cardiovascular perspective. Vol.46(5), PP.347-353, 2017.

[8] P.L.Jones, F.S.Jones. "Tenascin-C in development and disease: gene regulation and cell function". Matrix Biol. Vol. 19 (7), PP. 581-96, 2000.

[9] Ferrini, , Gm. Monica, F.Nestor, GonzalezCadavid, Jacob Rajfer, et al. Aging related erectile 
dysfunction-potential mechanism to halt or delay its onset. Transl Androl Urol. Vol.6(1), PP.20-27, 2017.

[10] A.Mohamed Elbendary, M.El.Osama A.Gamal, Khaled Salem. Analysis of risk factors for organic erectile dysfunction in Egyptian patients under the age of 40 years, J Androl. Vol.30(5), PP.520-4, 2009.

[11] K.Amin, A.Ekberg-Jansson, C.G. Lofdahl, P.Venge. Relationship between inflammatory cells and structural changes in the lungs of asymptomatic and never smokers: a biopsy study. Thorax . Vol.58, PP.135-142, 2003.

[12] R.M.Carrillo-Larco, A.C.Luza-Duenas , M.Urdaniga-Hung. Short Report: Epidemiology Diagnosis of erectile dysfunction can be used to improve screening for Type 2 diabetes mellitus. Diabet. Med, Vol.35,PP. 1538-1543 , 2018.

[13] Raquel Castellon, Sergio Caballero, K.Hamdi Hamdi, R.Shari Atilano, M.Annette Aoki, W.Roy Tarnuzzer, M. Cristina Kenney, B.Maria Grant, V.Alexander Ljubimov. Effects of tenascin-C on normal and diabetic retinal endothelial cells in culture. Vol.43(8), PP.2758-66, 2002.
[14]X.Wang, WHuang, Y.Zhang. Relation between hypertension and erectile dysfunction: a metaanalysis of cross-section studies.International Journal of Impotence Research . Vol.30(3), PP.141146, 2018.

[15]M.Stephanie Meller, Erik Stilp, N.Charles Walker, Carlos Mena-Hurtado. The link between vasculogenic erectile dysfunction, coronary artery disease, and peripheral artery disease: role of metabolic factors and endovascular therapy, Invasive Cardiol, 2013 Jun. Vol.25(6), PP.313-9, 2013.

[16] Prathap Kanagala, R.Jayanth Arnold, N.Jamal Khan, Anvesha Singh, S.Gaurav Gulsin, C. S.Daniel Chan, S. H. Adrian Cheng, Jing Yang, Li.Zhuyin , Pankaj Gupta, B.Iain Squire, P.Gerry. Mc.Cann, L. $\mathrm{Ng}$ Leong. Plasma Tenascin-C: a prognostic biomarker in heart failure with preserved ejection fraction, Received 24 Jun 2020, Accepted 01 Aug 2020, Accepted author version posted online. Vol.17 , PP. 566, 2015. 